\title{
SISTEM PENDUKUNG KEPUTUSAN PEMILIHAN DOSEN BERPRESTASI JURUSAN TEKNOLOGI INFORMASI DI POLITEKNIK NEGERI MALANG
}

\author{
Dwi Puspitasari ${ }^{1}$, Ahmadi Yuli Ananta ${ }^{2}$, Ervin Vidi Wicahya ${ }^{3}$ \\ 1,2,3 Teknologi Informasi, Teknik Informatika, Politeknik Negeri Malang \\ ${ }^{1}$ dwi.puspitasari@polinema.ac.id, ${ }^{2}$ ahmadi@polinema.ac.id, ${ }^{3}$ ervinvidiwicahya@gmail.com
}

\begin{abstract}
Abstrak
Penilaian prestasi dosen merupakan salah satu kegiatan yang diadakan setiap semester pada Jurusan Teknologi Informasi di Politeknik Negeri Malang. Kegiatan ini bertujuan untuk memberikan penghargaan pada Dosen sesuai dengan UU No 14 tahun 2005 tentang Guru dan Dosen, Pasal 51 Ayat (1) Butir b, bahwa Dosen berhak mendapatkan penghargaan sesuai dengan kinerja akademiknya. Pada Jurusan Teknologi Informasi penilaian prestasi dosen merupakan salah satu kegiatan yang diadakan setiap semester di Politeknik Negeri Malang. Adapun data kriteria yang dijadikan sebagai dasar penilaian yaitu kehadiran dosen, pengumpulan nilai, pengumpulan soal ujian, penilaian mahasiswa, jurnal, seminar, penelitian dan pengabdian kepada masyarakat. Untuk saat ini setiap dosen di Jurusan Teknologi Informasi harus memberikan secara langsung data penilaian tersebut dan admin harus menjumlahkan semua nilai yang terkumpul dari setiap dosen yang pada akhirnya membutuhkan waktu yang cukup lama dalam perhitungannya. Sehingga itu menjadi suatu permasalahan yang harus segera diselesaikan. Untuk mengatasi permasalahan tersebut maka dirancang sebuah sistem pendukung keputusan untuk pemilihan dosen berprestasi menggunakan Metode Simple Additive Weighting (SAW). Hasil akhir dari penelitian ini sistem dapat menampilkan hasil perangkingan untuk membantu dalam menentukan dosen berprestasi Jurusan Teknologi Informasi di Politeknik Negeri Malang, dengan cara menghitung dan memproses nilai prioritas atau bobot yang ditentukan dari setiap kriteria data yang dimasukkan.
\end{abstract}

Kata Kunci : SPK, pemilihan dosen berprestasi, metode $S A W$

\section{Pendahuluan}

Penyelenggaraan pendidikan di perguruan tinggi tak lepas dari peran dosen. Dosen merupakan tenaga akademik yang bertugas merencanakan dan melaksanakan proses pembelajaran, menilai hasil pembelajaran, melakukan pembimbingan dan pelatihan, serta melakukan penelitian dan pengabdian pada masyarakat. Berdasarkan Undang-undang Republik Indonesia No 14 tahun 2005 tentang Guru dan Dosen, Pasal 51 Ayat (1) Butir b, bahwa dosen berhak mendapatkan penghargaan sesuai dengan kinerjanya.

Pada Jurusan Teknologi Informasi penilaian prestasi dosen merupakan salah satu kegiatan yang diadakan setiap semester di Politeknik Negeri Malang. Adapun data kriteria yang dijadikan sebagai dasar penilaian yaitu kehadiran dosen, pengumpulan nilai, pengumpulan soal ujian, penilaian mahasiswa, jurnal, seminar, penelitian dan pengabdian kepada masyarakat. Untuk saat ini setiap dosen di Jurusan Teknologi Informasi harus memberikan secara langsung data penilaian tersebut dan admin harus menjumlahkan semua nilai yang terkumpul dari setiap dosen yang pada akhirnya membutuhkan waktu yang cukup lama dalam perhitungannya. Sehingga itu menjadi suatu permasalahan yang harus segera diselesaikan.
Pada penelitian kasus-kasus sebelumnya telah dilakukan penelitian mengenai Sistem Pendukung Keputusan Pemilihan Dosen Berprestasi di STMIK Tasikmalaya dengan menggunakan kriteria yang telah ditentukan. Hasil dari penelitian tersebut menyatakan bahwa algoritma Metode Simple Additive Weighting $(S A W)$ dapat digunakan sebagai salah satu metode untuk penentuan dosen yang berprestasi. Sistem Pendukung Keputusan Pemilihan Dosen Berprestasi di STMIK Tasikmalaya dengan menggunakan metode Metode Simple Additive Weighting (SAW) telah berhasil dibangun untuk menghasilkan keputusan berupa daftar perangkingan dosen berprestasi dan Sistem pendukung keputusan ini dibangun dengan melakukan penambahan kriteria-kriteria sehingga mampu mengurangi tingkat subjektifitas, dan berdampak pada hasil pemilihan terhadap dosen.

Dari permasalahan ini maka penulis mencoba untuk membangun sebuah sistem pendukung keputusan pemilihan dosen berprestasi yang di dalamnya mencakup proses pemilihan dosen berprestasi dengan menggunakan Metode Simple Additive Weighting $(S A W)$ sebagai algoritma proses perankingannya dengan mengacu pada relevansi - relevansi yang digunakan sebagai data rujukan. 


\section{Landasan Teori \\ 2.1 Kinerja Dosen}

Kinerja Dosen merupakan suatu kemampuan yang ditunjukan oleh dosen dalam melaksanakan tugas atau pekerjaannya. Kinerja dikatakan baik dan memuaskan apabila hasil yang dicapai sesuai dengan standar yang telah ditetapkan. Pada studi kasus ini standar penilaian yang digunakan sebagai acuan pemilihan dosen berprestasi dapat dilihat pada tabel 1 .

Tabel 1. Standar Kriteria Penilaian

\begin{tabular}{|l|l|c|l|}
\hline \multicolumn{4}{|c|}{ Kriteria Penilaian } \\
\hline C1 & Kehadiran Dosen & C5 & Jurnal \\
\hline C2 & Pengumpulan Nilai & C6 & Seminar \\
\hline C3 & $\begin{array}{l}\text { Pengumpulan Soal } \\
\text { Ujian }\end{array}$ & C7 & Penelitian \\
\hline C4 & $\begin{array}{l}\text { Penilaian } \\
\text { Mahasiswa }\end{array}$ & C8 & $\begin{array}{l}\text { Pengabdian } \\
\text { Masyarakat }\end{array}$ \\
\hline
\end{tabular}

\subsection{Sistem Pendukung Keputusan}

Sistem pendukung keputusan (SPK) adalah bagian dari sistem informasi berbasis komputer termasuk sistem berbasis pengetahuan atau manajemen pengetahuan yang dipakai untuk mendukung pengambilan keputusan dalam suatu organisasi atau perusahaan. Dapat juga dikatakan sebagai sistem komputer yang mengolah data menjadi informasi untuk mengambil keputusan dari masalah semi terstruktur yang spesifik.

Sistem pendukung keputusan (SPK) mulai dikembangkan pada tahun 1960-an, tetapi istilah sistem pendukung keputusan itu sendiri baru muncul pada tahun 1971, yang diciptakan oleh G. Anthony Gorry dan Micheal S.Scott Morton, keduanya adalah profesor di MIT. Hal itu mereka lakukan dengan tujuan untuk menciptakan kerangka kerja guna mengarahkan aplikasi komputer kepada pengambilan keputusan manajemen.

\subsection{Metode Simple Additive Weighting (SAW)}

Menurut Fishburn dan MacCrimmon dalam (Munthe, 2013) mengemukakan bahwa Metode Simple Additive Weight (SAW), sering juga dikenal dengan istilah metode penjumlahan terbobot. Konsep dasar Metode Simple Additive Weighting (SAW) adalah mencari penjumlahan terbobot dari rating kinerja pada setiap alternatif pada semua atribut.

Kriteria penilaian dapat ditentukan sendiri sesuai dengan kebutuhan perusahaan.

\section{Langkah-langkah dalam Metode $S A W$ adalah :}

1. Memberikan nilai bobot preferensi (W) oleh pengambil keputusan untuk masing-masing kriteria yang sudah ditentukan:

$W=\left[\begin{array}{lllll}W_{1} & W_{2} & W_{3} & \ldots & W_{j}\end{array}\right]$

Keterangan :

$\mathrm{W}=$ Nilai bobot dari kriteria

$W_{j} \quad=$ Nilai bobot untuk setiap kriteria

2. Melakukan normalisasi matriks keputusan $\mathrm{Z}$ dengan cara menghitung nilai rating kinerja ternormalisasi $\left(r_{i j}\right)$ dari alternatif $A_{i}$ pada atribut $C_{j}$.

$$
r_{i j}=\left\{\begin{array}{l}
\frac{x_{i j}}{M A X_{i}\left(x_{i j}\right)} \\
\frac{M I N_{i}\left(x_{i j}\right)}{x_{i j}}
\end{array}\right.
$$

Keterangan :

$r_{i j} \quad=$ Nilai rating kinerja ternomalisasi

$x_{i j}=$ Nilai atribut yang dimiliki setiap

kriteria

$M A X_{i j} \cdot x_{i j}=$ Nilai terbesar dari setiap kriteria $\operatorname{MIN}_{i j} \cdot x_{i j}=$ Nilai terkecil dari setiap kriteria

Dengan ketentuan :

a. Dikatakan atribut keuntungan apabila atribut banyak memberikan keuntungan bagi pengambil keputusan, sedangkan atribut biaya merupakan atribut yang banyak memberikan pengeluaran jika nilainya semakin besar bagi pengambil keputusan.

b. Apabila berupa atribut keuntungan maka nilai $\left(x_{i j}\right)$ dari setiap kolom atribut dibagi dengan nilai $\left(M A X x_{i j}\right)$ dari tiap kolom, sedangkan untuk atribut biaya, nilai $\left(M I N x_{i j}\right)$ dari tiap kolom atribut dibagi dengan nilai $\left(x_{i j}\right)$ setiap kolom.

3. Hasil dari nilai rating kinerja ternormalisasi $\left(r_{i j}\right)$ membentuk matriks ternormalisasi $(\mathrm{R})$.

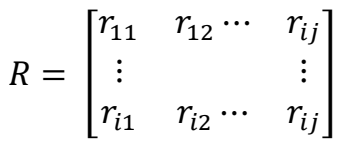

Keterangan :

$R \quad=$ Matriks hasil normalisasi

4. Melakukan proses perankingan dengan cara mengalikan matriks ternormalisasi $(\mathrm{N})$ dengan nilai bobot preferensi (W).

5. Menentukan nilai preferensi untuk setiap alternatif $\left(V_{i}\right)$ dengan cara menjumlahkan hasil kali antara matriks ternormalisasi $(\mathrm{N})$ dengan nilai bobot preferensi $(\mathrm{W})$. 


$$
V_{i}=\sum_{j=1}^{n} w_{j} r_{i j}
$$

\section{Keterangan :}

$V_{i} \quad=$ Rating untuk setiap alternatif

$W_{j} \quad=$ Nilai bobot untuk setiap kriteria

$r_{i j} \quad=$ Nilai rating kinerja ternormalisasi

Nilai $V_{i}$ yang lebih besar mengindikasikan bahwa alternatif $A_{i}$ lebih terpilih.

\section{Metode penelitian \\ 3.1 Metode Pencarian Data}

Untuk Mendapatkan data yang benar-benar akurat, relevan valid (sahih) atau reliable maka penulis mengumpulkan data dengan cara melakukan pengamatan (observasi) terhadap objek dan subjek penelitian secara langsung. Dimana objek pada penelitian ini adalah "Dosen" dan subjeknya adalah data kriteria penilaian dosen yang dapat dilihat pada tabel 1.

\subsection{Metode Pengolahan Data}

\section{A. Menentukan Kriteria}

Kriteria yang diperlukan dalam pengambilan keputusan pemilihan dosen berprestasi Jurusan Teknologi Informasi di Politeknik Negeri Malang dapat dilihat pada tabel 1.

\section{B. Menentukan Bobot Kriteria}

Setelah ditentukan data kriteria kemudian tentukan bobot kepentingan pada setiap kriteria. Adapun tabel bobot kepentingan dapat dilihat pada table 2 .

\section{Tabel 2. Bobot Kriteria}

\begin{tabular}{|l|l|l|}
\hline Kode & Kriteria & Bobot \\
\hline C1 & Kehadiran Dosen & 0,15 \\
\hline C2 & Pengumpulan Nilai & 0,05 \\
\hline C3 & Pengumpulan Soal Ujian & 0,05 \\
\hline C4 & Penilaian Mahasiswa & 0,1 \\
\hline C5 & Jurnal & 0,15 \\
\hline C6 & Seminar & 0,1 \\
\hline C7 & Penelitian & 0,25 \\
\hline C8 & $\begin{array}{l}\text { Pengabdian kepada } \\
\text { Masyarakat }\end{array}$ & 0,15 \\
\hline
\end{tabular}

C. Menentukan Rating Kecocokan

Setelah data kriteria dan bobot kepentingan yang disebutkan pada tabel 1 dan 2, kemudian dibuatlah rating kecocokan setiap alternatif terhadap setiap kriteria menggunakan skala 1 sampai 5 yang dapat dilihat pada tabel 3

Tabel 3. Rating Kecocokan

\begin{tabular}{|c|l|}
\hline Nilai & Keterangan \\
\hline 1 & Sangat Kurang \\
\hline 2 & Kurang \\
\hline 3 & Cukup \\
\hline 4 & Baik \\
\hline 5 & Sangat Baik \\
\hline
\end{tabular}

D. Input Penilaian

Dari hasil pengumpulan data yang didapatkan ketika observasi dan wawancara, maka didapatkan sampel dari kandidat dosen berprestasi tersebut yaitu dapat dilihat pada tabel 4.

Tabel 4. Nilai Inputan

\begin{tabular}{|l|c|c|c|c|c|c|c|c|}
\hline \multirow{2}{*}{$\begin{array}{c}\text { Altern } \\
\text { atif }\end{array}$} & \multicolumn{10}{|c|}{ Kriteria } \\
\cline { 2 - 9 } & $\mathbf{C}$ & $\mathbf{C 2}$ & $\mathbf{C}$ & $\mathbf{C 4}$ & $\mathbf{C}$ & $\mathbf{C}$ & $\mathbf{C}$ & $\mathbf{C}$ \\
\hline \multirow{2}{*}{ Dosen1 } & 10 & $\mathrm{H}$ & $\mathrm{H}$ & 84. & 2 & 4 & 2 & 4 \\
& 0 & & -7 & 3 & & & & \\
\hline Dosen2 & 10 & $\mathrm{H}+$ & $\mathrm{H}$ & 79 & 2 & 2 & 2 & 2 \\
& 0 & 1 & -5 & & & & & \\
\hline Dosen & 99 & $\mathrm{H}+$ & $\mathrm{H}$ & 80. & 2 & 2 & 1 & 4 \\
3 & & 1 & -3 & 23 & & & & \\
\hline Dosen & 10 & $\mathrm{H}-$ & $\mathrm{H}$ & 84. & 2 & 2 & 2 & 2 \\
4 & 0 & 6 & -1 & 9 & & & & \\
\hline $\begin{array}{l}\text { Dosen } \\
5\end{array}$ & 98 & $\mathrm{H}$ & $\mathrm{H}$ & 81. & 2 & 2 & 2 & 2 \\
\hline
\end{tabular}

Berdasarkan tabel 4, selanjutnya dapat dibentuk rating kecocokan dari setiap alternatif pada setiap kriteria seperti yang terlihat pada tabel 5.

Tabel 5 Rating Kecocokan Setiap Alternatif

\begin{tabular}{|l|c|c|c|c|c|c|c|c|}
\hline \multirow{2}{*}{ Alternatif } & \multicolumn{7}{|c|}{ Kriteria } \\
\cline { 2 - 10 } & C1 & C2 & C3 & C4 & C5 & C6 & C7 & C8 \\
\hline Dosen 1 & 5 & 3 & 5 & 5 & 4 & 5 & 4 & 5 \\
\hline Dosen 2 & 5 & 2 & 5 & 4 & 4 & 4 & 4 & 4 \\
\hline Dosen 3 & 5 & 2 & 4 & 5 & 4 & 4 & 4 & 5 \\
\hline Dosen 4 & 5 & 5 & 3 & 5 & 4 & 4 & 4 & 4 \\
\hline Dosen 5 & 5 & 3 & 3 & 5 & 4 & 4 & 4 & 4 \\
\hline
\end{tabular}

Setelah tahap rating kecocokan selesai kemudian dilanjutkan dengan langkah membuat matriks keputusan X. Matriks ini dibuat dari tabel 3.4 rating kecocokan sebagai berikut ini:

$$
X=\left[\begin{array}{l}
53554545 \\
52544444 \\
52454445 \\
55354444 \\
53354444
\end{array}\right]
$$

Langkah selanjutnya melakukan Normalisasi matriks X untuk menghitung nilai masing - masing 
kriteria berdasarkan kriteria yang diasumsikan sebagai kriteria keuntungan. Untuk cara perhitungannya dapat dilihat pada poin 2.3 Metode Simple Additive Weighting pada rumus No. 2. Kemudian didapati hasil dari nilai rating kinerja ternormalisasi $\left(r_{i j}\right)$ membentuk matriks ternormalisasi $(\mathrm{R})$.

$$
\mathrm{R}=\left[\begin{array}{llllllll}
1 & 0,6 & 1 & 1 & 1 & 1 & 1 & 1 \\
1 & 0,4 & 1 & 0,8 & 1 & 0,8 & 1 & 0,8 \\
1 & 0,4 & 0,8 & 1 & 1 & 0,8 & 1 & 1 \\
1 & 1 & 0,6 & 1 & 1 & 0,8 & 1 & 0,8 \\
1 & 0,6 & 0,6 & 1 & 1 & 0,8 & 1 & 0,8
\end{array}\right]
$$

Selanjutnya, melakukan proses perankingan dengan cara mengalikan matriks ternormalisasi (R) dengan nilai bobot preferensi (W) dan Menentukan nilai preferensi untuk setiap alternatif (Vi) dengan cara menjumlahkan hasil kali antara matriks ternormalisasi dengan nilai bobot preferensi (W). Untuk nilai bobot preferensi/vektor bobot (W) oleh pengambil keputusan untuk masing-masing kriteria yang sudah ditentukan yaitu :

$$
W=[0,15|0,05| 0,05|0,1| 0,15|0,1| 0,25 \mid 0,15]
$$

Kemudian didapatkan hasil perangkingan seperti dalam tabel 6 sebagai berikut:

Tabel 6 Hasil Perhitungan Nilai $V_{i}$

\begin{tabular}{|c|c|c|}
\hline Alternatif & $\begin{array}{c}\text { Hasil Nilai } \\
\boldsymbol{V}_{\boldsymbol{i}}\end{array}$ & Ranking \\
\hline$V_{1}$ & 0,98 & 1 \\
\hline$V_{2}$ & 0,9 & 5 \\
\hline$V_{3}$ & 0,94 & 2 \\
\hline$V_{4}$ & 0,93 & 3 \\
\hline$V_{5}$ & 0,91 & 4 \\
\hline
\end{tabular}

Berdasarkan hasil pengujian pada sistem aplikasi terkomputerisasi, maka alternatif yang memiliki nilai tertinggi bisa dijadikan sebagai data pertimbangan untuk dipilih sebagai dosen berprestasi. Pada tabel 3 dapat diambil suatu kesimpulan bahwa alternatif $V_{1}$ (Calon Dosen Berprestasi) yang memiliki nilai tertingi pertama dengan nilai final 0,98 kemudian nilai tertinggi kedua adalah $V_{3}$ dengan nilai final 0,94 selanjutnya nilai tertinggi ke tiga adalah $V_{4}$ dengan nilai final 0,93 kemudian nilai tertinggi ke empat adalah $V_{5}$ dengan nilai final 0,91 dan nilai tertinggi ke lima adalah $V_{2}$ dengan nilai final 0,9 .

Dengan demikian alternatif $V_{1}$ (Dosen 1) adalah yang terpilih sebagai alternatif terbaik untuk meraih prestasi sebagai dosen berprestasi, sehingga bisa digunakan sebagai data pertimbangan atau pendukung untuk dipilih menjadi dosen berprestasi pada jurusan teknologi informasi di Politeknik Negeri Malang

\subsection{Metode Pengembangan}

Dalam membantu penyusunan penelitian ini, struktur kerja yang akan diterapkan pada sistem ini menggunakan konsep dan alur dari Waterfall dimana metode ini memiliki 5 (lima) tahapan yaitu Requirement, design, Implementation, Verification, dan Maintenance sebagaimana diungkapkan dalam referensi [5].

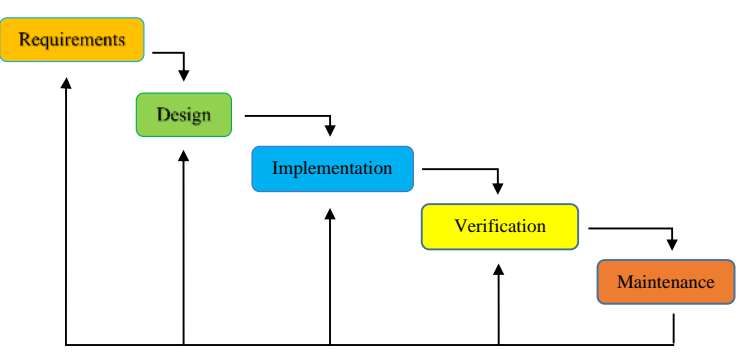

Gambar 1. Metode Pengembangan Waterfall

Tahapan-tahapan dalam Waterfall yang tersusun secara sistematis adalah sebagai berikut :

1. Konsep (Requirements)

Tahap konsep merupakan tahap awal dalam siklus Waterfall. Pada tahap konsep, dimulai dengan menentukan tujuan pembuatan aplikasi serta penggunaa aplikasi tersebut. Kemudian dilanjutkan dengan melakukan analisa terhadap kebutuhan sistem. Pengumpulan data dalam tahap ini bisa malakukan sebuah penelitian, wawancara atau study literatur.

2. Perancangan (Design)

Konsep yang sudah matang akan memudahkan dalam menggambarkan apa yang harus dilakukan. Tujuan dari tahap perancangan adalah membuat spesifikasi secara terperinci mengenai arsitektur proyek, tampilan dan kebutuhan material proyek serta gaya.

3. Implementasi (Implementation)

Tahap Implementation adalah tahap final dalam pembuatan sebuah sistem. Setelah melakukan analisa, design dan pengkodean maka sistem yang sudah jadi akan digunakan oleh user atau pengguna sistem.

4. Verifikasi (Verification)

Tahap Verification adalah tahap pembuatan keseluruhan bahan multimedia. Aplikasi yang akan dibuat didasarkan pada tahap desain, dan sesuai rancangan Flow Chart

5. Perawatan (Maintenance)

Proses ini dilakukan ketika sistem informasi sudah dioperasikan. Pada tahapan ini dilakukan monitoring proses, evaluasi dan perubahan (perbaikan) bila diperlukan. 


\section{Analisa dan perancangan}

\subsection{Analisis Sistem}

Analisis sistem merupakan suatu penjelasan mengenai komponen-komponen penyusun sistem pada penelitian ini. Analisa dilakukan pada perangkat lunak (software) dan perangkat keras (hardware) dan desain arsitektur sistem yang akan dirancang.

\subsection{Perancangan Arsitektur Sistem}

Sistem yang dibangun merupakan sistem pendukung keputusan pemilihan dosen berprestasi Jurusan Teknologi Informasi di Politeknik Negeri Malang berbasis web yang dapat diakses oleh user melalui komputer. Desain arsitektur sistem pendukung keputusan pemilihan dosen berprestasi dapat dilihat pada Gambar 2 sebagai berikut

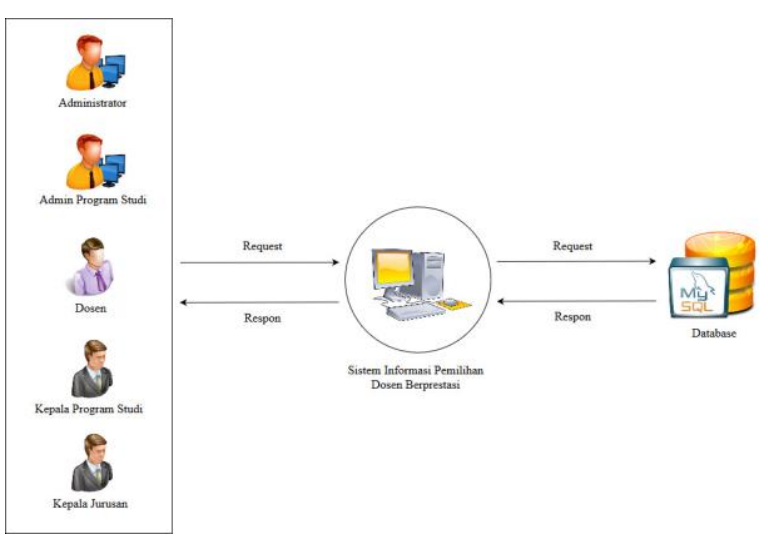

Gambar 2. Arsitektur SPK pemilihan dosen berprestasi

\subsection{Use Case Diagram Administrator}

Use case diagram administrator mendeskripsikan hubungan-hubungan yang terjadi antara aktor dengan aktivitas yang terjadi pada sebuah sistem.

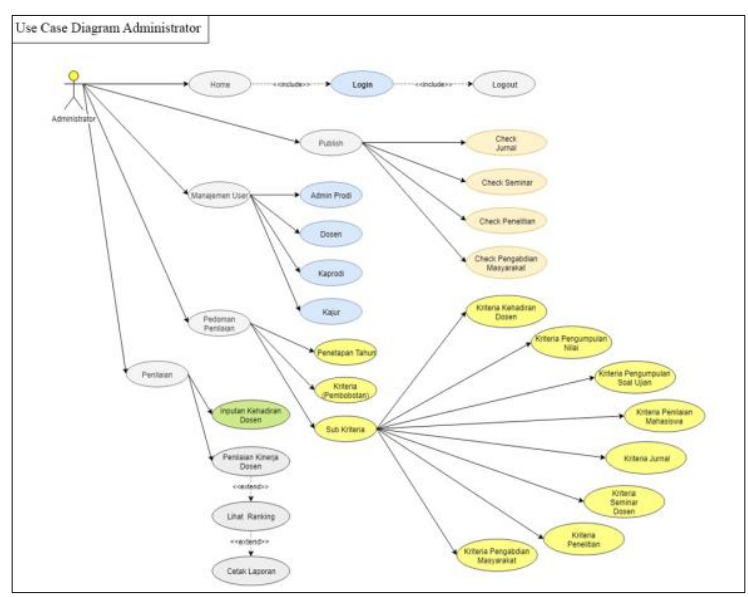

Gambar 3. Use Case Diagram Administrator

\subsection{Use Case Diagram Admin Program Studi}

Use case diagram admin program studi mendeskripsikan hubungan-hubungan yang terjadi antara aktor dengan aktivitas yang terjadi pada sebuah sistem.

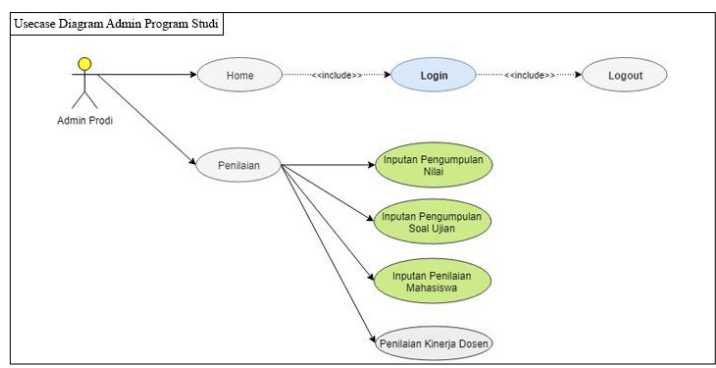

Gambar 4. Use Case Diagram Admin Program Studi

\subsection{Use Case Diagram Ketua Prodi dan Ketua Jurusan}

Use case diagram Ketua Prodi dan Ketua Jurusan mendeskripsikan hubungan-hubungan yang terjadi antara aktor dengan aktivitas yang terjadi pada sebuah sistem..

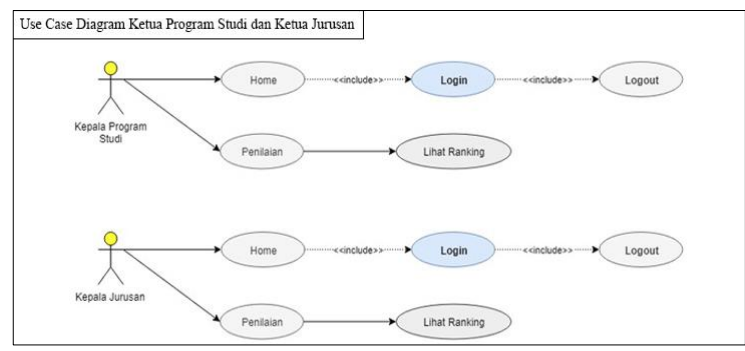

Gambar 5. Use Case Diagram Ketua Prodi dan Ketua Jurusan

\subsection{Use Case Diagram Dosen}

Use dase diagram dosen mendeskripsikan hubungan-hubungan yang terjadi antara aktor dengan aktivitas yang terjadi pada sebuah sistem. Aktor dalam sistem adalah pengguna, sedangkan sistem adalah aplikasi SPK Pemilihan Dosen Berprestasi. 


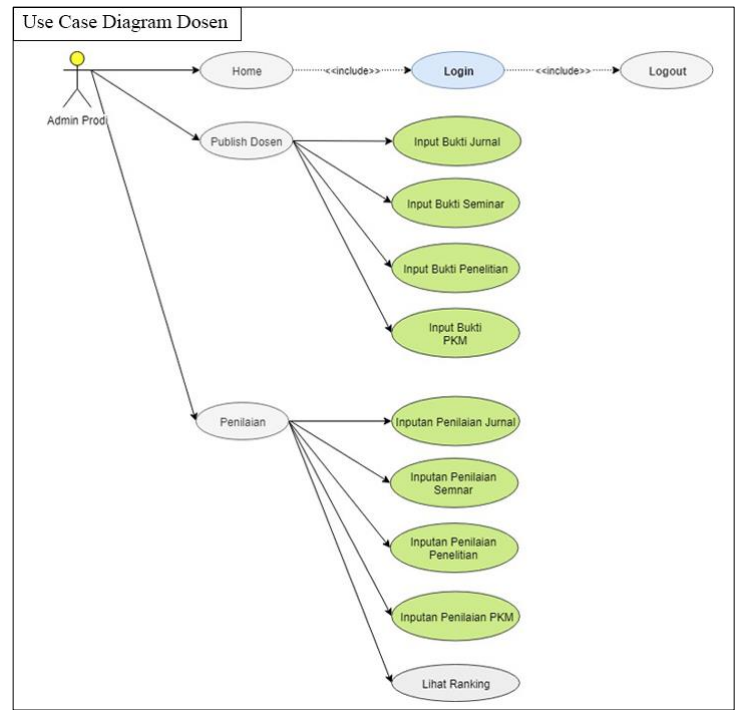

Gambar 6. Use Case Diagram Dosen

\subsection{Entity Relationship Diagram (ERD)}

Entity Relationship Diagram (ERD) digunakan dalam pemodelan data dan akan membantu mengorganisasikan data dalam suatu proyek ke dalam entitas entitas dan menentukan entitas beserta atributatributnya.

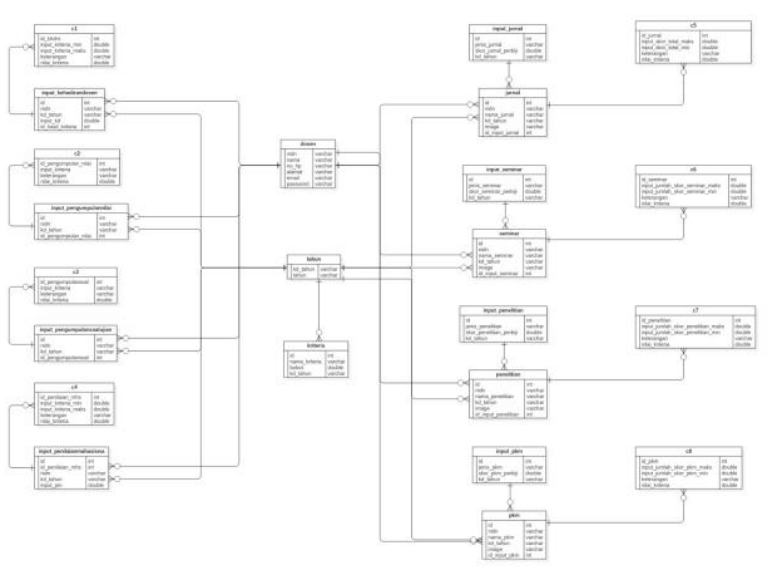

Gambar 6. Entity Relationship Diagram (ERD)

\section{Implementasi}

Pada bab implementasi membahas rangkaian implementasi sistem setelah perancangan aplikasi selesai dilakukan. Tahap mengimplementasikan kebutuhan-kebutuhan sistem yang dapat menunjang pembuatan sistem tersebut. Implementasi pada sistem pendukung keputusan pemilihan dosen berprestasi ini menggunakan Laravel sebagai Framewok.

\subsection{Implementasi Interface}

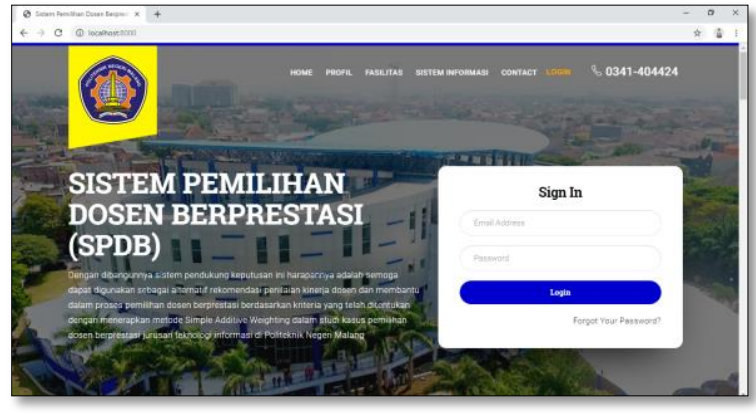

Gambar 7. Halaman Welcome

Pada Gambar 7. menunjukan tampilan halaman awal ketika pertama kali membuka aplikasi sistem pendukung keputusan pemilihan dosen berprestasi.

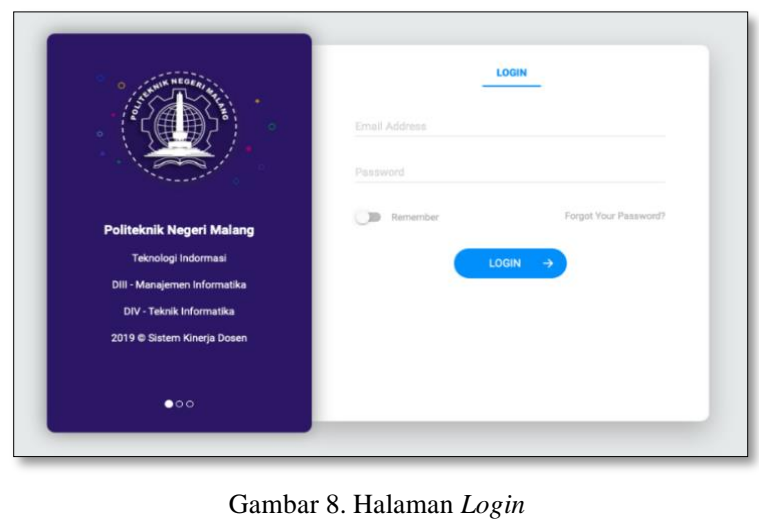

Pada Gambar 8. Antarmuka halaman login berisi form login untuk proses verifikasi pengguna sistem baik itu administrator, admin program studi, dosen, ketua prodi dan ketua jurusan. Apabila 5 data login yang telah dimasukkan sesuai, maka pengguna dapat mengakses menu-menu yang ada pada sistem sesuai role yang ditentukan.

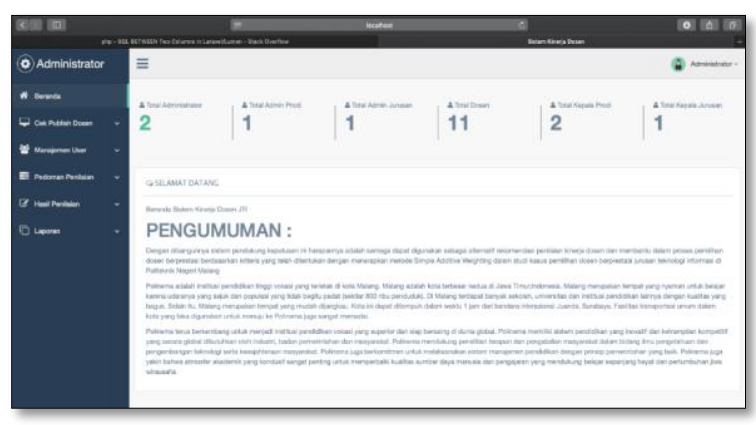

Gambar 9. Halaman Home

Pada Gambar 9. Form home ini merupakan tampilan halaman utama pada aplikasi SPDB JTI Polinema setelah melakukan proses login sistem. 


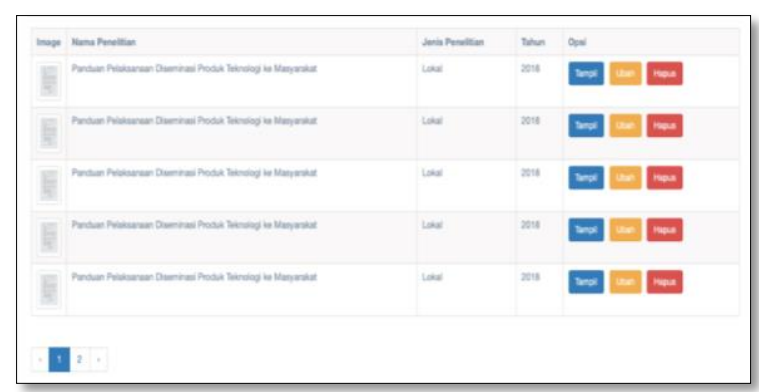

Gambar 10. Halaman Cek Data Publish

Pada gambar 10. Halaman cek data publish ini digunakan oleh administrator sebagai alat bantu atau pedoman dalam melakukan proses pemindaian atau pemeriksaan terkait data yang diinputkan oleh dosen untuk mendapatkan data yang benar-benar valid atau bisa dibuktikan kebenarannya.

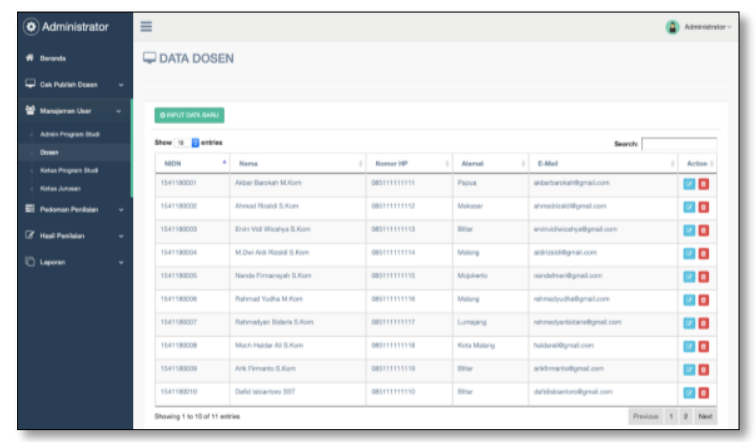

Gambar 11. Halaman Manajemen User

Pada gambar 11. Halaman ini digunakan untuk melakukan proses pendaftaran user baru dengan akses role yang ditentukan (admin program studi, dosen, ketua prodi dan ketua jurusan).

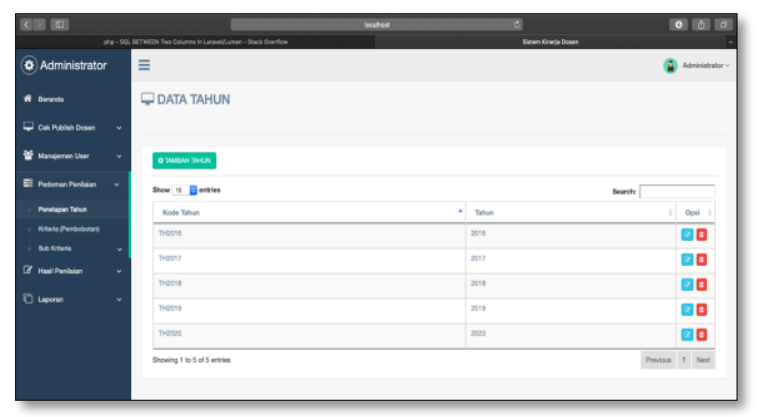

Gambar 12. Halaman Penetapan Tahun

Pada gambar 12. Halaman ini digunakan untuk setiap data yang berkaitan dengan relasi tahun.

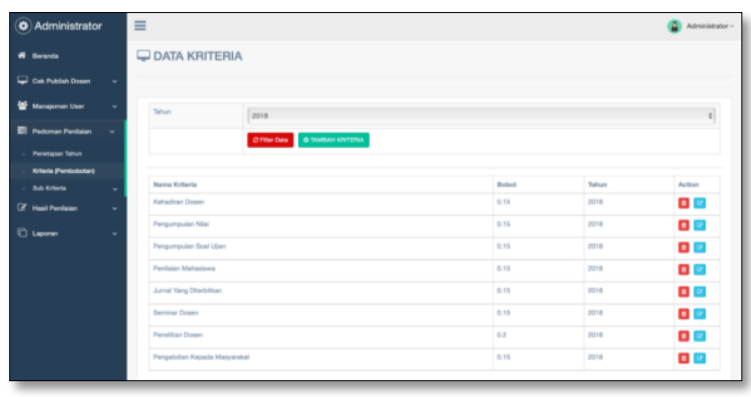

Gambar 13. Halaman Kriteria Pembobotan

Pada gambar 13. Halaman kriteria (pembobotan) ini digunakan untuk perhitungan perkalian matriks ternormalisasi (R) dengan nilai bobot preferensi (W) dan menentukan nilai preferensi untuk setiap alternative (Vi) dengan menjumlahakan hasil kali antara matriks ternormalisasi dengan nilai bobot preferensi (W).

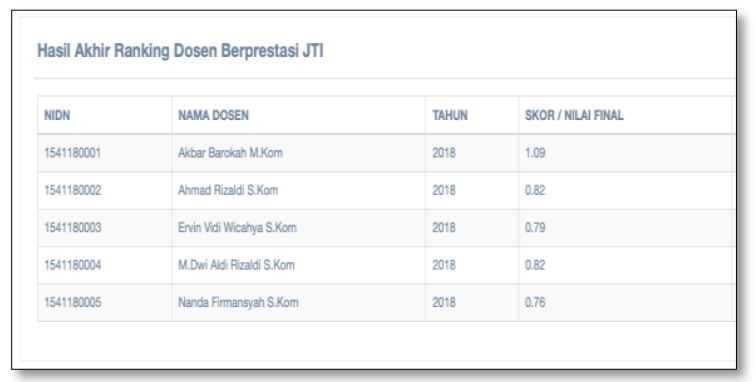

Gambar 14. Halaman Penilain (Ranking)

Pada gambar 14. Halaman penilaian digunakan untuk proses perhitungan metode serta menampilkan hasil dari proses perhitungan metode berupa alternatif perankingan.

\section{Pengujian}

Perancangan beserta implementasi telah dilakukan maka selanjutnya perlu dilakukan beberapa pengujian untuk mengetahui cara kerja dari perangkat dan menganalisa tingkat keakuratan, kelemahan serta keterbatasan spesifikasi dari aplikasi dan rangkaian yang telah dibuat. Selain itu pengujian ini juga dilakukan untuk mengetahui tentang bagaimana pengkondisian sistem agar aplikasi ini dapat digunakan dengan optimal.

\subsection{Pengujian Kuisioner}

Kuesioner disebarkan menggunakan teknik sampling yaitu Simple Random Sampling yang disebarkan kepada 9 responden. Dari hasil kuesioner tersebut akan dilakukan perhitungan agar dapat diambil kesimpulan terhadap penilaian penerapan sistem yang baru. Kuesioner ini terdiri dari 5 pertanyaan (contoh kuesioner dapat dilihat pada lampiran). 
Pertanyaan yang muncul pada pengujian beta ini adalah sebagai berikut:

1. Apakah Bapak/Ibu dosen setuju bahwa tampilan sistem pendukung keputusan pemilihan dosen berprestasi jurusan teknologi informasi di Politeknik Negeri Malang cukup menarik dan mudah dioperasikan/user friendly?

2. Apakah Bapak/Ibu dosen setuju dengan adanya aplikasi ini dapat membantu dalam proses pemilihan dosen berprestasi jurusan teknologi informasi di Politeknik Negeri Malang?

3. Apakah Bapak/Ibu dosen setuju dengan adanya aplikasi ini dapat membantu untuk memberikan informasi dosen terpilih sebagai dosen berprestasi jurusan teknologi informasi di Politeknik Negeri Malang secara akurat?

4. Apakah aplikasi mempunyai kemampuan dan fungsi sesuai yang diharapkan?

5. Secara keseluruhan apakah penggunaan aplikasi ini memuaskan?

Berdasarkan data hasil kuisioner tersebut, dicari prosentase masing - masing jawaban dengan menggunakan rumus berikut:

$$
R=\frac{P}{Q} * 100 \%
$$

Keterangan :

$\mathrm{P}=$ Jumlah responden dengan tingkat pengetahuan

Q = Jumlah Keseluruhan Responden

$\mathrm{R}=$ Nilai Prosentase

\begin{tabular}{|c|c|c|c|c|c|c|c|}
\hline & \multicolumn{6}{|c|}{ Jumlah Pernyataan } & Jumlah Responden \\
Pada Kuisioner & $\begin{array}{c}\text { Prosentase } \\
\text { Sesuai Dengan } \\
\text { Tingkat }\end{array}$ & $\begin{array}{c}\text { Interpretasi } \\
R=\frac{P}{Q} * 100 \%\end{array}$ \\
& SS & $\mathbf{S}$ & BS & TS & STS & $\begin{array}{c}\text { Tinyaan } \\
\text { Pengetahuan (P) }\end{array}$ & \\
\hline P1 & 5 & 4 & 0 & 0 & 0 & 41 & $91,1 \%$ \\
\hline P2 & 6 & 3 & 0 & 0 & 0 & 42 & $93,3 \%$ \\
\hline P3 & 4 & 5 & 0 & 0 & 0 & 40 & $88,8 \%$ \\
\hline P4 & 2 & 6 & 1 & 0 & 0 & 37 & $82,2 \%$ \\
\hline P5 & 3 & 6 & 0 & 0 & 0 & 39 & $86,6 \%$ \\
\hline
\end{tabular}

Keterangan :

$\mathrm{Q}=$ Jumlah responden $* 5$ Pernyataan $(\mathrm{SS}, \mathrm{S}, \mathrm{BS}, \mathrm{TS}$, STS)

$$
\begin{aligned}
& =9 * 5 \\
& =45
\end{aligned}
$$

Perhitungan Hasil Prosentase Responden:

$\mathrm{P} 1=5.5+4.4+3.0+2.0+1.0=41$

Sehingga PI $=\frac{41}{45} * 100=91,1 \%$

$\mathrm{P} 2=5.6+4.3+3.0+2.0+1.0=42$
Sehingga PI $=\frac{42}{45} * 100=93,3 \%$

$\mathrm{P} 3=5.4+4.5+3.0+2.0+1.0=40$

Sehingga PI $=\frac{40}{45} * 100=88,8 \%$

$\mathrm{P} 4=5.2+4.6+3.1+2.0+1.0=37$

Sehingga PI $=\frac{37}{45} * 100=82,2 \%$

$\mathrm{P} 5=5.3+4.6+3.0+2.0+1.0=39$

Sehingga $\mathrm{PI}=\frac{39}{45} * 100=86,6 \%$

Prosentase interprestasi kuisoner responden dapat dilihat pada gambar 15 .

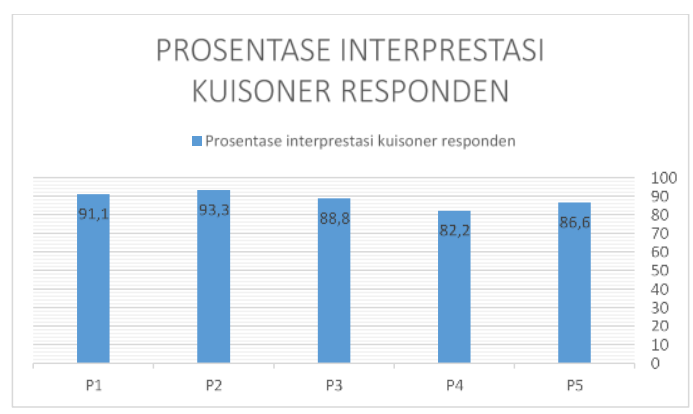

Gambar 14. Prosentase Interprestasi Kuisoner Responden

P1. Tampilan aplikasi menarik (user friendly)

$\mathrm{P} 2$. Membantu proses pemilihan dosen berprestasi

P3. Membantu dalam memberikan informasi dosen berprestasi yang terpilih

P4. Aplikasi mempunyai kemampuan dan fungsi sesuai yang diharapkan

P5. Penggunaan aplikasi memuaskan

Prosentase interprestasi kuisoner digunakan untuk mengukur kesesuaian aplikasi ini. Pengguna dapat menilai dan mengukur layak atau tidaknya aplikasi yang dibuat. Berikut adalah keterangan hasil prosentasenya :

1) P1 menghasilkan prosentase interpretasi $91,1 \%$ dengan hasil tampilan aplikasi menarik (user friendly).

2) $\mathrm{P} 2$ menghasilkan prosentase interpretasi $93.3 \%$ dengan hasil aplikasi dapat membantu proses pemilihan dosen berprestasi.

3) P3 menghasilkan prosentase interpretasi $88,8 \%$ dengan hasil aplikasi dapat membantu dalam memberikan informasi dosen berprestasi yang terpilih.

4) P4 menghasilkan prosentase interpretasi $82.2 \%$ dengan hasil aplikasi mempunyai kemampuan dan fungsi sesuai yang diharapkan.

5) P5 menghasilkan prosentase interpretasi $86,6 \%$ dengan hasil penggunaan aplikasi memuaskan. 


\section{Kesimpulan}

Dari penelitian yang telah dilakukan maka dapat diambil kesimpulan sebagai berikut:

1. Berdasarkan permasalahan dan pembahasan diatas dapat disimpulkan bahwa sistem telah berhasil dan dapat digunakan untuk membantu dalam menghitung dan memproses dengan metode Simple Additive Weighting dalam penentuan pemilihan dosen berprestasi jurusan teknologi informasi di Politeknik Negeri Malang yang sesuai dengan kriteria yang telah ditentukan yaitu kehadiran dosen, pengumpulan nilai, pengumpulan soal ujian, penilaian mahasiswa, jurnal, seminar, penelitian, pengabdian kepada masyarakat..

2. Penerapan sistem pendukung keputusan pemilihan dosen berprestasi jurusan teknologi informasi di Politeknik Negeri Malang berhasil diterapkan pada bentuk sistem perankingan.

3. Metode Simple Additive Weighting (SAW) mampu menyelesaikan persoalan suatu pemilihan dengan model menggunakan nilai prioritas atau bobot yang ditentukan setiap kebutuhan.

4. Metode Simple Additive Weighting (SAW) mampu mendukung keputusan pemilihan dosen berprestasi dengan memberikan perangkingan dari setiap alternatif.

\section{Daftar Pustaka:}

Mufizar, T. (2016). Sistem Pendukung Keputusan Pemilihan Dosen Berprestasi Di STMIK Tasikmalaya Menggunakan Metode Simple Additive Weighting (SAW). CSRID (Computer Science Research and Its Development Journal), 7(3), 155. https://doi.org/10.22303/csrid.7.3.2015.155166.

Safrizal, S. (2014). Rekam Jejak Dosen Sebagai Model Pengambilan Keputusan Dalam Pemilihan Dosen Berprestasi. Creative Information Technology Journal, 2(1), 65-76. Retrieved from

http://citec.amikom.ac.id/main/index.php/citec/ article/view/38.

Maryaningsih, Siswanto, M. (2013). Metode Logika Fuzzy Dalam Sistem Pengambilan Keputusan Penerimaan Beasiswa. Jurnal Media Infotama, 9(1), 140-165. Retrieved from https://ejournal.medan.uph.edu/index.php/isd/a rticle/download/109/33.

Metode, P., Additive, S., \& Saw, W. (2016). DALAM SISTEM PENDUKUNG KEPUTUSAN PROMOSI, (1), 37-45.

Muzzammil, T. R., Ginardi, R. V. H., \& Purwitasari, D. (2016). Modul Klasifikasi Aduan dengan Pendekatan Kemiripan Teks pada Aplikasi Perangkat Bergerak Suara Warga (SURGA)
Kota Kediri, 5(1), 52-57. https://doi.org/10.2307/4126447.

M. Astiningrum et al., "Implementasi nlp dengan konversi kata pada sistem chatbot konsultasi laktasi," vol. 5, no. November, pp. 46-52, 2018.

Rohman, A. (2014). Mengenal Framework "Laravel" ( Best PHP Frameworks For 2014 ).

Strata, P. S., Teknik, J., \& Fakultas, I. (2017). Sistem pendukung keputusan pemilihan handphone dengan metode simple additive weighting (saw) berbasis web.

Strata, P. S., Teknik, J., \& Fakultas, I. (2017). Sistempendukung keputusan pemilihan handphone dengan metode simple additive weighting (saw) berbasis web.

Sujaini, H., Pratiwi, H. S., \& Sofhian. (2016). Sistem Pendukung Keputusan Pemilihan Dosen Terbaik Menggunakan Metode Promethee ( Studi Kasus : Teknik Informatika Universitas Tanjungpura ). Jurnal Sistem Dan Teknologi Informasi (JUSTIN), 1(1), 1-6. https://doi.org/10.1007/s11032-011-9559-9. 
Volume 6, Edisi 4, Agustus 2020

$46 \mid \mathrm{H}$ a 1 a $\mathrm{m}$ a $\mathrm{n}$ 